( К. О. Чепурна, канд. техн. наук, доц., О. І. Хмілярчук, канд. техн. наук, доц., К. О. Колчина, магістр, КПІ ім. Ігоря Сікорського, Київ, Україна

\title{
ДОСЛІДЖЕННЯ ЯКОСТІ ВІДТВОРЕННЯ ШТРИХОВИХ ЗОБРАЖЕНЬ ТРАФАРЕТНИМ ДРУКОМ НА ТКАНИНАХ
}

В роботі наведено результати дослідження впливу технологічних параметрів трафаретного друку на якість відтворення штрихової інформації; проаналізовано вплив Фактури та товщини волокна тканини на графічну точність відтворення штрихових зображень та рівномірність плашок. Встановлено, що для фактур тканин, які мають певний напрямок волокон і виражений рисунок поверхні, напрямок друку вздовж або впоперек напряму волокон має значення; товщина волокна тканини також впливає на величину розтискування, але в комплексі з видом переплетення та щільність за ступенем заповнення нитками. За результатами аналізу проведених досліджень сформульовано рекомендації щодо трафаретного друку на тканинах.

Ключові слова: трафаретний друк; розтискування; тканина; текстильне волокно; штрихова інформація; фактура тканини.

Постановка проблеми

Якісно брендована текстильна продукція $є$ невід'ємним атрибутом для створення іміджу компанії та популяризації бренду, а також широко використовується під час проведення промоакцій, виставок, конкурсів, спортивних змагань та багатьох інших заходів.

Нанесення інформації на тканинні вироби - це простий та економічно вигідний засіб реклами. Потенційні клієнти завжди позитивно сприймають рекламні подарунки, такі як брендовані екосумки, футболки, світшоти або прапорці.
Залежно від вимог, які ставляться до задруковуваної текстильної продукції, виду текстильного волокна, характеру зображення обирається той чи інший спосіб нанесення зображення $[1,2]$. Кожному способу притаманні деякі спотворення зображення на готових виробах, які проявляються у зміні колірних, градаційних та графічних показників.

Чимало досліджень, присвячених впливу технологічних параметрів трафаретного друку на якість відбитків, наведено в роботах [3-7], але без врахування специфіки друку на тканинах, що є ак-

(с) Автор(и) 2020. Видавець КПІ ім. Ігоря Сікорського.

CC BY 4.0 (https://creativecommons.org/licenses/by/4.0/). 
туальним завдяки інтенсивному розвитку цього напряму трафаретного друку.

\section{Аналіз попередніх досліджень}

Для задруковування трафаретним друком доступно безліч найрізноманітніших видів паперів, картонів, пластиків, тканин, металів, скляних та дерев'яних поверхонь. Безумовно, трафаретний друк має цілу низку переваг порівняно з іншими технологіями, наприклад, використання однієї універсальної друкарської машини та різних видів фарб і лаків, для нанесення зображення на будь-які поверхні; досягнення високої покривної здатності фарбового шару.

Але при друці на фактурних поверхнях виникає спотворення зображення, що проявляється у «проваленні» фарби в структуру задруковуваного матеріалу та спричиняє нерівномірний розподіл фарби на поверхні відбитка. Ще однією проблемою $є$ використання для друку тонованих в масі задруковуваних матеріалів. Цілком очевидно, що багатофарбовий друк на не білих задруковуваних матеріалах повинен здійснюватися або із попереднім нанесенням білого підкладу, або із урахуванням колірних спотворень на відбитку. При друкуванні, наприклад, на металізованих картонах без білого підкладу можна отримувати певні ефекти, які дизайнер повинен враховувати, працюючи над зображенням. Ці та інші проблеми частково висвітлені в літературі [5-8], наприклад, у роботі [9] зазначено, що стійкість зображення, нанесеного трафаретним друком, до впливу зовнішніх факторів під час використання текстильної продукції, є вищою порівняно з сублімаційним друком. Значно менше досліджено вплив специфіки технологічного процесу трафаретного друку та виду тканини на якість нанесених зображень.

\section{Мета роботи}

Визначення впливу технологічних параметрів трафаретного друку, фактури задруковуваних матеріалів, напряму друку відносно неї на якісні показники штрихових зображень, отриманих на тканинах.

\section{Результати проведених досліджень}

Для дослідження розроблено тест-форму із врахуванням виду переплетення, товщини волокна тканини та фактури картону. Тест-форма містить такі контрольні ділянки: плашкові поля, позитивні та негативні штрихи товщиною 0,2 мм, 0,3 мм, 0,5 мм, $1 \mathrm{Mм}, 2$ мм, 3 мм.

Для проведення досліджень обрано чотири зразка тканин, які характеризуються вираженою фактурою, характеристики зразків наведено в табл. 1.

Для дослідження обрано настільний ручний вузол трафаретного друку; враховуючи товщину штрихів, у розробленій тестформі, обрано трафаретне сито із комплексного поліефірного полотна Sefar PET/120/34/Y/ PW: лініатура сітки 120 лін./см, товщина 34 мкм, фарбоване Yellow, переплетення полотняне 1:1; для друку використано трафаретну фарбу Argon Vinilfast 36.000 E, колір 305 (коричневий), при їі 
виборі враховано тип задруковуваних матеріалів. Під час проведення попередніх досліджень, встановлено оптимальні параметри друкарського ракелю: матеріал - поліуретан; ширина 120 мм, твердість 75 од. за Шором А; робоча поверхня - прямокутна; технологічні параметри друку: кут нахилу ракеля до поверхні друкарської форми 75; технологічний зазор 3 мм; напрям друку вздовж та впоперек фактури задруковуваного матеріалу.

Для оцінювання якості відбитків застосовано інструментальний та візуальний контроль. На основі проведених вимірювань

Таблиця 1

Вид задруковуванного матеріалу та їх характеристики

\begin{tabular}{|c|c|c|}
\hline $\begin{array}{c}\text { № } \\
\text { зраз- } \\
\text { ка }\end{array}$ & Вид та характеристика зразка & Фото зразка \\
\hline 1 & $\begin{array}{l}\text { Стрейч-кулір, тканина двостороння: лицьо- } \\
\text { ва сторона вертикальні «колоски»; виворотна - } \\
\text { «цеглинки». } \\
\text { Виражена фактура, за ступенем заповнення } \\
\text { нитками - помірно розріджена. } \\
\text { Частка синтетичних волокон в матеріалі } \\
\text { в середньому 5-8 \%. } \\
\text { Товщина волокна 0,12 мм. }\end{array}$ & के. \\
\hline 2 & $\begin{array}{l}\text { Трикотажний нейлон, тканина односторон- } \\
\text { ня: лицьова та зворотна сторони вертикальні } \\
\text { «колоски». } \\
\text { Помірно виражена фактура, рівномірно } \\
\text { щільна; за ступенем заповнення нитками - } \\
\text { щільна. } \\
\text { Синтетична тканина молочного кольору, } \\
\text { виготовлена з поліамідних волокон (55 \% } \\
\text { нейлону і } 45 \text { \% віскози). } \\
\text { Товщина волокна 0,14 мм. }\end{array}$ & 6 \\
\hline 3 & $\begin{array}{l}\text { Льон, полотняне переплетення, поверхня } \\
\text { лицьової та зворотної сторони рівномірна. } \\
\text { Фактура класичної сітки полотняного перепле- } \\
\text { тення, нерівнощільна (збільшена щільність } \\
\text { по основі); за ступенем заповнення нитка- } \\
\text { ми - розріджена. } \\
\text { Товщина волокна 0,29 мм. }\end{array}$ & 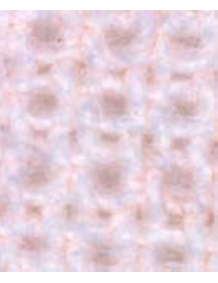 \\
\hline 4 & $\begin{array}{l}\text { Льон, полотняне переплетення, поверхня } \\
\text { лицьової та зворотної сторони рівномірна. } \\
\text { Фактура класичної сітки полотняного перепле- } \\
\text { тення, рівнощільна; за ступенем заповнення } \\
\text { нитками - розріджена (ширина між волокнами } \\
\text { майже дорівнює товщині волокна). } \\
\text { Товщина волокна 0,57 мм. }\end{array}$ & \\
\hline
\end{tabular}


визначено графічне спотворення штрихової інформації на кожному із зразків. Враховуючи, що на величину розтискування впливає багато технологічних параметрів, а саме, тиск та швидкість друку, величина технологічного зазору, в'язкість фарби, дослідження проводили з максимальним дотриманням їх постійних значень, для того, щоб виявити вплив, саме фактури та характеру задруковуваної поверхні, на відтворення штрихових і плашкових контрольних елементів.

На рис. 1 наведено значення графічного спотворення штрихових контрольних полів залежно від фактури поверхні та напряму друку, відносно фактури. Штрихові елементи товщиною 0,2/0,3/ 0,5 мм мають значне розтискування, для зразків 1-2 це пояснюється, тим що ширина волокна менша за ширину штрихового елементу і присутня характерно виражена фактура поверхні та вбирна здатність (рис. 1, а, б). Значний відсоток розтискуван- ня, для зразків 3-4 (рис. 1, в), пояснюється саме будовою тканини: достатньо розріджена, натуральна ворсиста тканина, тому частина штрихової інформації, попадаючи у комірки між волокнами, втрачається, а частина добре вбирається у волокнами. Загалом, отримані результати свідчать про те, що величина графічних спотворень для ліній товщиною до 0,5 мм для зразків 1-2 при друкуванні впоперек фактури більша, для зразків 3-4 напрям друку немає значення, так як фактура $€$ однаковою в обох напрямах.

Для штрихів товщиною від 1 мм характерне зниження розтискування для всіх зразків, і в цілому, краще відтворення при друці вздовж фактури. Тому при підготовці макетів необхідно враховувати можливе розтискування, яке буде спричинене не лише фактурою матеріалу, але і напрямом друку відносно фактури. Супутній вплив на розтискування має вбирна здатність та щіль-

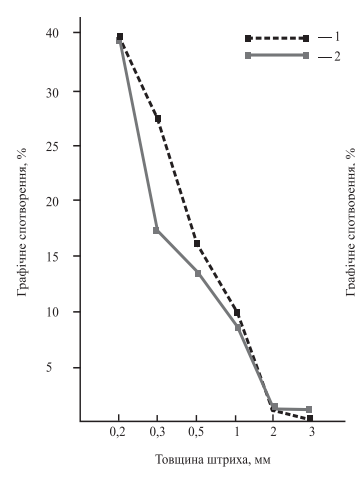

a

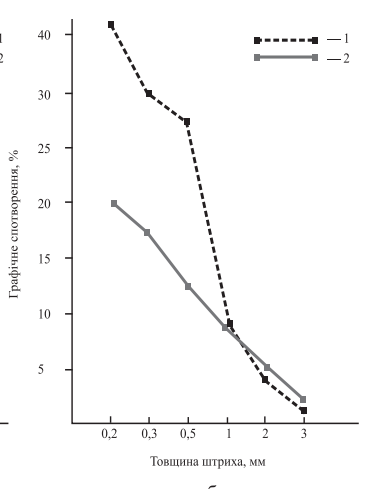

6

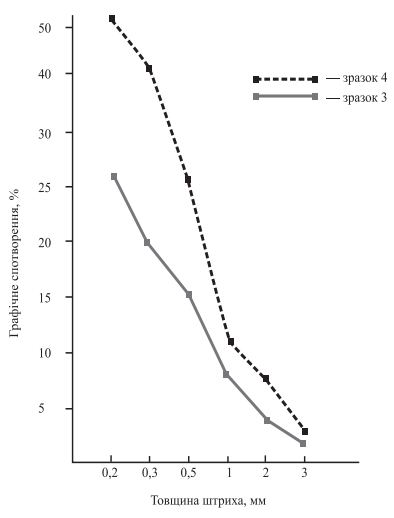

B

Рис. 1. Залежність графічного спотворення від напряму друку: а - зразок 1; б - зразок 2; 1 - друк впоперек напряму волокон, 2 - друк вздовж напряму волокон; в - зразок 3 та 4 
ність матеріалу, тому для розріджених тканин, більш вигідний варіант плашкових зображень та штрихів товщиною від 3 мм.

За результатами дослідження, виявлено вплив товщини волокна тканини на графічну точність зображення (рис. 2). Загальна тенденція полягає в тому, що зі збільшенням товщини волокна відбувається зменшення величини розтискування, але за умови, що тканина має мінімально виражену фактуру, є помірно щільною та має більший відсоток синтетичних волокон у своєму складі, що буде перешкоджати надмірній вбирній здатності (рис. 2, б (зразок 2)). Саме, більш вираженою фактурою, мінімальною часткою синтетичного волокна у складі, малою товщиною волокна, яка менша ширини елементів зображення, пояснюється значне розтискування на зразку 1 (рис. 2, б): негативні та позитивні штрихи товщиною до 1 мм відтворюються рваними, провалюються у фактуру матеріалу. Для зразків 3-4 (рис. 2, а), які мають більшу товщину волокна, відтворення штрихів товщиною до 1 мм виявилося проблемним, тому що частина зображення попадає у комірки між волокнами. На основі аналізу, отриманих результатів, для тканин, які мають подібні характеристики до зразків 3-4, рекомендовано використовувати переважно плашкові зображення, ретельно підбирати в'язкість друкарської фарби, для уникнення значного всотування у товщу волокон тканини, рекомендовано використання текстильних пластизольних фарб або УФ-фарб [5, 10].

Проведено візуальну оцінку відтворення штрихових позитивних та негативних контрольних елементів зображення, детальний аналіз наведено в табл. 2. Плашкові контрольні поля на всіх зразках відтворюються достатньо

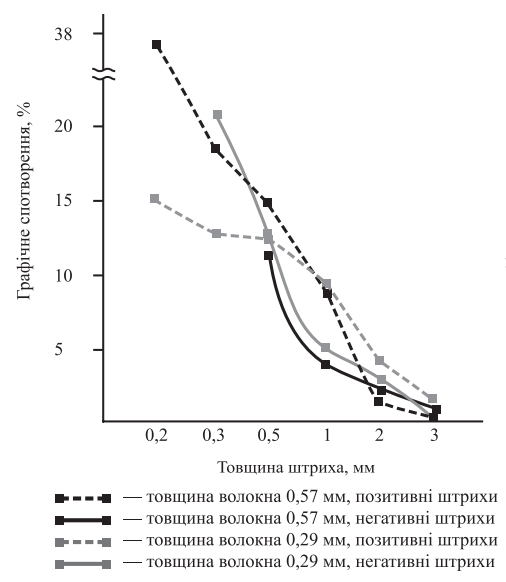

a

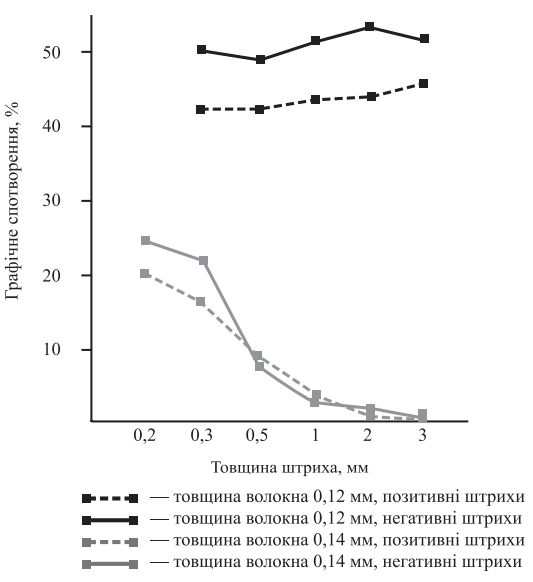

6

Рис. 2. Залежність графічного спотворення від товщини волокна тканини:

а - зразок тканини 4, товщина волокна 0,57 мм; зразок тканини 3, товщина волокна 0,29 мм; б - зразок тканини 1, товщина волокна 0,12 мм; зразок тканини 2, товщина волокна 0,14 мм 
Візуальна оцінка якості відтворення зображення

\begin{tabular}{|c|c|}
\hline Негативне контрольне поле & Позитивне контрольне поле \\
\hline \multicolumn{2}{|c|}{ Зразок 1} \\
\hline 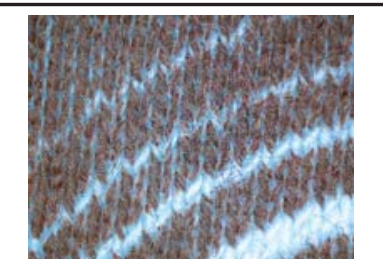 & 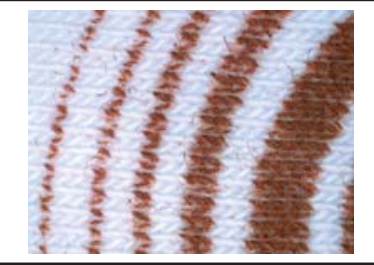 \\
\hline
\end{tabular}

На зразку 1 штрихи товщиною до 1 мм відтворюються зі значним спотворенням, негативні заливаються завдяки ворсистості та фактури матеріалу; позитивні штрихи мають рвані краї завдяки наявній фактурі. Оптималььне відтворення штрихів товщиною від 2 мм

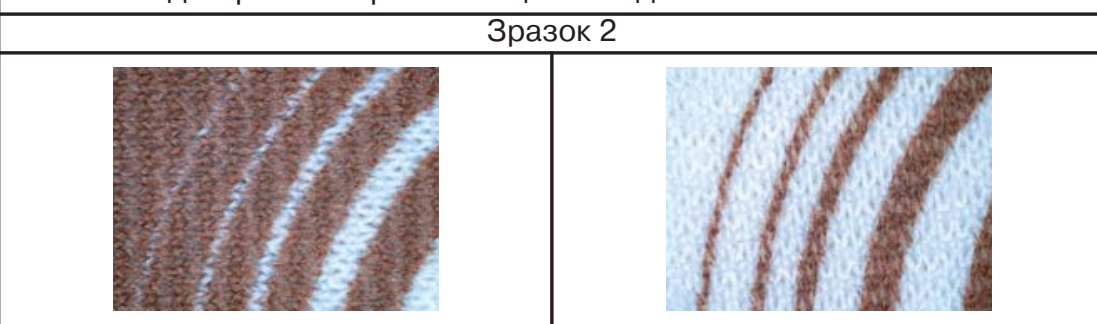

На зразку 2 позитивні штрихи всіх товщин відтворюють задовільно; негативні контрольні елементи товщиною до 0,5 мм відтворюються зі спотворенням, оптимальне відтворення штрихів товщиною від 0,5 мм

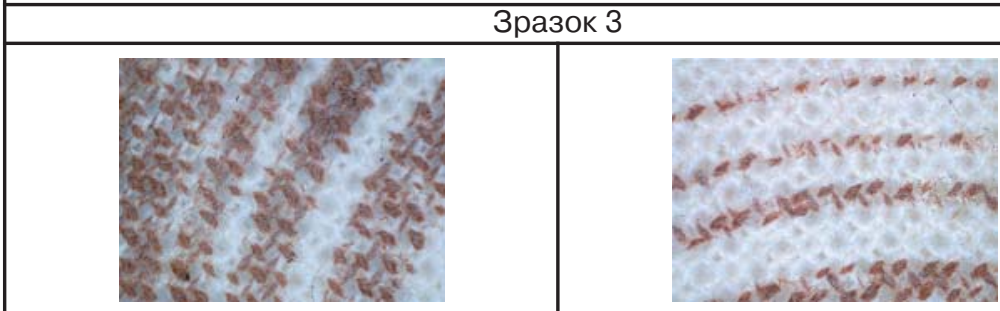

На зразку 3 негативні та позитивні штрихи товщиною до 1 мм відтворюються зі значним спотворенням, у негативі відбувається заливання проміжків, а у позитиві пропадання штрихів, завдяки ворсистості та фактури матеріалу. Оптимальне відтворення штрихів товщиною від 2 мм

\begin{tabular}{|l|l|l|}
\hline \multicolumn{3}{|c|}{ Зразок 4} \\
\hline \\
\hline
\end{tabular}

На зразку 4 негативні та позитивні штрихи товщиною до 1 мм відтворюються зі значним спотворенням, у негативі відбувається заливання проміжків, а у позитиві пропадання штрихів завдяки ворсистості та фактури матеріалу. Оптимальне відтворення штрихів товщиною від 2 мм 
задовільно, якщо взяти до уваги, що текстильна продукція сприймається з певної відстані.

\section{Висновки}

Встановлено, що мінімальні спотворення штрихових елементів на тканинах спостерігаються у тому випадку, якщо тканина відповідає наступним вимогам: фактура тканини помірно виражена, рівнощільна по основі та по утку, за ступенем заповнення нитками - щільна, має в своєму складі частку синтетичних волокон.

За результатами аналізу проведених досліджень сформульовано наступні рекомендації щодо трафаретного друку на тканинах:

- для друку необхідно обирати тканини з рівномірною фактурою, мінімально вираженим рельєфом та щільним переплетенням ниток;
- встановлено, що напрям друку впливає на якість отриманих відбитків. Величина графічних спотворень для ліній товщиною до 1 мм для досліджуваних видів тканин при друкуванні впоперек структури волокон більша, тому для кожної тканини потрібно індивідуально розробляти макет зображення для уникнення значних спотворень, не використовувати штрихи товщиною менше одного міліметру;

- при друкуванні на натуральних матеріалах зі значною ворсистістю, шорсткістю поверхні треба враховувати неминучі спотворення, які виникнуть при цьому, тому необхідно ретельно готувати оригінал-макет до друку, особливо враховувати товщину мінімального графічного елементу.

\section{Список використаної літератури}

1. Хмілярчук О. І. Аналітичний огляд технологій перенесення зображення на тканину / О. І. Хмілярчук, А. Д. Шепельова // Технологія і техніка друкарства. 2017. № 1(55). C. 38-46. DOI: https://doi.org/10.20535/20777264.1(55).2017.90086.

2. Розум Т. В. Технологічні особливості та систематизація способів термотрансферного друку / Т. В. Розум, О. М. Нечипорчук // Технологія і техніка друкарства. 2008. № 2(20). C. 47-58. DOI: https://doi.org/10.20535/20777264.2(20).2008.59769.

3. Зоренко О. В. Оцінка якості відбитків трафаретного друку / О. В. Зоренко, О. Ю. Байдак, К. В. Сидоренко, Б. Р. Кушлик // Технологія і техніка друкарства. 2016. № 1(51). C. 75-84. DOI: https://doi.org/10.20535/2077-7264.1(51).2016.72156.

4. Маїк В. 3. Аналіз впливу технологічних факторів на якість рельєфних зображень на відбитках трафаретного друку / В. 3. Маїк, М. С. Харів // Квалілогія книги. 2014. № 1(25). С. 17-21.

5. Рибка Р. В. Дослідження впливу підкладки-основи на якість зображення трафаретного друку УФ-фарбами / Р. В. Рибка, П. М. Ривак // Квалілогія книги. 2014. № 2(26). С. 16-20.

6. Чепурна К. О. Відтворення штрихових зображень на фактурних поверхнях трафаретним способом друку / К. О. Чепурна, І.В.Ковальська // XVIII Міжнародна науково-практична конференція з проблем видавничополіграфічної галузі: тези доповідей. Київ. 15.05.2014. С. 20-22. 
7. Чепурна К. О. Фактори впливу на якість відбитків, отриманих трафаретним способом друку / К. О. Чепурна, І. В. Ковальська // XXI Міжнародна науково-практична конференція 3 проблем видавничо-поліграфічної галузі: тези доповідей. Київ. 17.11.2015. С. 111-113.

8. Мотика М. Т. Технологічні фактори впливу на товщину фарбового шару на відбитках трафаретного друку / М. Т. Мотика, Е. Т. Лазаренко // Квалілогія книги. Львів: УАД, 2010. № 2(18). С. 70-74.

9. Савчук О. В. Дослідження якості друкованих малюнків, нанесених на трикотажне полотно різними способами / О. В. Савчук, Л. Є. Галавська // Технології та дизайн: електрон. наук. фах. вид. / Київ. нац. ун-т технологій та дизайну. 2018. № 1(26). Режим доступу: https://nbuv.gov.ua/UJRN/td_2018_1_10.

10. Ковальчук А. М. Дослідження якості відтворення зображень у трафаретному друці / А. М. Ковальчук, Н. Д. Лотошинська, Л. Я. Маїк // Поліграфія і видавнича справа. Львів: УАД, 2020. № 1(79). С. 78-88.

\section{References}

1. Khmiliarchuk, O. I. \& Shepelova, A. D. (2017). Analitychnyi ohliad tekhnolohii perenesennia zobrazhennia na tkanynu [Analytical Review of the Technologies of Transferring Images on Fabric]. Tekhnolohiia i tekhnika drukarstva, 1(55), 38-46. DOI: https://doi.org/10.20535/2077-7264.1(55).2017.90086 [in Ukrainian].

2. Rozum, T. V. \& Nechyporchuk, O. M. (2008). Tekhnolohichni osoblyvosti ta systematyzatsiia sposobiv termotransfernoho druku [Technological features and ordering of ways of heat transfer printing]. Tekhnolohiia i tekhnika drukarstva, 2(20), 47-58. DOI: https://doi.org/10.20535/2077-7264.2(20).2008.59769 [in Ukrainian].

3. Zorenko, O. V. \& Baidak, O. Yu. \& Sydorenko, K. V. \& Kushlyk, B. R. (2016). Otsinka yakosti vidbytkiv trafaretnoho druku [Assessment of the Quality of the Imprints of Screen Printing]. Tekhnolohiia i tekhnika drukarstva, 1(51), 75-84. DOI: https://doi.org/10.20535/2077-7264.1(51).2016.72156 [in Ukrainian].

4. Maik, V. Z. \& Khariv, M. S. (2014). Analiz vplyvu tekhnolohichnykh faktoriv na yakist reliefnykh zobrazhen na vidbytkakh trafaretnoho druku [Analysis of the Influence of Technological Factors on the Quality of Relief Images on the Imprints of Screen Printing]. Kvalilohiia knyhy, № 1(25), 17-21 [in Ukrainian].

5. Rybka, R. V. \& Ryvak, P. M. (2014). Doslidzhennia vplyvu pidkladky-osnovy na yakist zobrazhennia trafaretnoho druku UF-farbamy [Investigation of the Influence of the Substrate-base on the Image Quality of Screen Printing with UV Inks]. Kvalilohiia knyhy, 2(26), 16-20 [in Ukrainian].

6. Chepurna, K. O. \& Kovalska, I. V. (2015). Vidtvorennia shtrykhovykh zobrazhen na fakturnykh poverkhniakh trafaretnym sposobom druku [Reproduction of Line Images on Textured Surfaces by Screen Printing]. Proceedings of the XVIII Mizhnarodna naukovo-praktychna konferentsiia z problem vydavnycho-polihrafichnoi haluzi. (pp. 111-113) [in Ukrainian].

7. Chepurna, K. O. \& Kovalska, I. V. (2015). Faktory vplyvu na yakist vidbytkiv, otrymanykh trafaretnym sposobom druku [Factors Influencing the Quality of Imprints Obtained by Screen Printing]. Proceedings of the XXI Mizhnarodna naukovo-praktychna konferentsiia z problem vydavnycho-polihrafichnoi haluzi. (111-113) [in Ukrainian].

8. Motyka, M. T. \& Lazarenko, E. T. (2010). Tekhnolohichni faktory vplyvu na tovshchynu farbovoho sharu na vidbytkakh trafaretnoho druku [Technological Factors Influencing the Thickness of the Ink Layer on the Imprints of Screen Printing]. Kvalilohiia knyhy, 2(18), 70-74 [in Ukrainian]. 
9. Savchuk, O. V. \& Halavska, L. Ye. (2018). Doslidzhennia yakosti drukovanykh maliunkiv, nanesenykh na trykotazhne polotno riznymy sposobamy / [Research of Quality of the Printed Drawings Put on a Knitted Cloth in Various Ways]. Tekhnolohii ta dyzain, 1(26). Retrieved from https://nbuv.gov.ua/UJRN/ td_2018_1_10 [in Ukrainian].

10. Kovalchuk, A. M. \& Lotoshynska, N. D. \& Maik, L. Ya. (2020). Doslidzhennia yakosti vidtvorennia zobrazhen u trafaretnomu drutsi [Research of Quality of Reproduction of Images in Screen Printing]. Polihrafichia i vydavnycha sprava, 1(79), 78-88 [in Ukrainian].

The scientific work presents the results of the study of the influence of technological parameters of screen printing on the quality of reproduction of line art information by screen

printing method; the influence of the texture and thickness of the fabric fiber on the graphic accuracy of line images reproduction and uniformity of solid image is analyzed. Instrumental and visual control was used to assess the quality of the prints.

Based on the measurements, the graphical distortion of the line art information on each of the samples was determined.

Keywords: screen printing method; dot gain; fabrics; textile fiber; line art information; fabric texture. 